MARIAN KANIOR OSB

\title{
STUDENCI WYDZIALU TEOLOGICZNEGO UNIWERSYTETU JAGIELLOŃSKIEGO W WOLNYM MIEŚCIE KRAKOWIE
}

\section{STAN OGÓLNY LICZBA STUDENTÓW WYDZIALU TEOLOGICZNEGO}

Jeszcze pod koniec XVIII wieku, w Krakowie, obok Wydziału Teologicznego na Akademii Krakowskiej, były jeszcze trzy seminaria: tzw. akademickie w sąsiedztwie uniwersytetu pod zarządem profesorów Akademii; drugie zamkowe (arcense) pod zarządem misjonarzy i trzecie, diecezjalne, na Stradomiu, również pod zarządem misjonarzy. Seminarium akademickie kształciło młodzież duchowną $z$ wyższym wykształceniem, natomiast pozostale dwa seminaria przygotowywały młodzież przez dwa lata do święceń kaplańskich. Za Austrii, dekret rządowy z dnia 18 III 1801 r. polecił konsystorzowi zamknąć seminarium akademickie i zamkowe, a nowe zarządzenie z 23 XII tegoż roku inkorporowalo oba te instytuty do seminarium misjonarskiego na Stradomiu ${ }^{1}$.

$\mathrm{Z}$ chwilą zamknięcia seminarium akademickiego jedną $\mathrm{z}$ najgłówniejszych bolączek Wydziału Teologicznego stal się brak studentów, gdyż Wydzial zostal pozbawiony większej części słuchaczy. Za pierwszej okupacji austriackiej wladze - zgodnie z prawodawstwem i zwyczajami rządowymi - po prostu nakazały alumnom seminarium uczęszczać na wykłady uniwersyteckie. Nie pomogły nawet józefińskie podręczniki w planie wykładów podane w 1801 r. komisji rządowej przez rektora seminarium, ks. J. K. Górnickiego ${ }^{2}$.

1 S. Wysocki, Seminarium zamkowe w Krakowie. Lwów 1910, s. 35; B. Kumor, Ustrój i organizacja Kościola polskiego w okresie niewoli narodowej (1792-1918). Kraków 1980, s. 388.

2 Por. T. Glemma, Wydzial Teologiczny Uniwersytetu Jagielloniskiego w latach 1796 1847. W: Polonia Sacra 1948, s. 77. 
Za Księstwa Warszawskiego przyznano biskupowi krakowskiemu przewodnictwo w Dozorze Szkoły Glównej i najwyższą władzę nad Wydziałem Teologicznym. W oparciu o swoją władzę biskup Andrzej Rawa Gawroński (1804-1814) - po wyjeździe benedyktynów niemieckich - postaral się dla rektora seminarium stradomskiego, ks. J.K. Górnickiego, o nominację na dziekana Wydziału Teologicznego. Wykłady odbywały się w seminarium ${ }^{3}$.

W okresie Rzeczypospolitej Krakowskiej, gdy odcięto Kraków i najbliższą okolicę kordonem od reszty Polski, uniwersytet, a więc i Wydział Teologiczny, cierpial na stały niedobór studentów. „Mocarstwa opiekuńcze" utrudniały jak tylko mogly swym poddanym studia na uczelni krakowskiej, wreszcie zakazując ich zupełnie. Samo stutysięczne Wolne Miasto mogło dostarczyć tylko małą liczbę studentów, tak że niekiedy profesorowie miewali po jednym studencie ${ }^{4}$. M. Kulczykowski mocno podkreśla, że tak niskiego stanu liczebnego studentów, jak w pierwszej połowie XIX wieku nie notowano w ciągu kilkuwiekowej historii Uniwersytetu Jagiellońskiego ${ }^{5}$. Brak słuchaczy tym dotkliwiej odczuwano na Wydziale Teologicznym, z uwagi na seminarium diecezjalne, odciągające znaczą liczbę kandydatów na studia teologiczne ${ }^{\sigma}$. Jeśli się weźmie pod uwagę, że studia teologiczne $w$ tym okresie trwały trzy lata, to na poszczególnych latach było bardzo niewielu uczniów ${ }^{7}$.

${ }^{3}$ Prof. Hechel pisał pod rokiem 1840/1841: „Dziś... tak mało jest uczniów na uniwersylecie, iż na mojej lekcji historii medycyny tylko jednego mam ucznia Ethingera i to jeszcze Żyda, który jako prawowierny izraelita, w szabas i inne swoje święta na lekcje nie przychodzi i ja wraz z nim święta żydowskie obchodzić muszę". Pamiętniki wyd. Wł. Szumowski II. Kraków 1939, s. 58. Por. także T. Glemma, Wydzial Teologiczny..., s. 75.

${ }^{5}$ M. Kulczykowski, Analiza zhiorowości studenckiej w pierwszej polowie XIX wieku (studium statystyczne). W: Studia z dziejów mlodzieży Uniwersytetu Krakowskiego od Oświecenia do polowy $X X$ wieku. T. 2. cz. 1 pod redakcją C. Bobińskiej. Kraków 1970, s. 28.

- Należy zwrócić uwagę, że diecezja krakowska po reorganizacji terytorialnej administracji kościelnej bullą Ex imposita nohis z 1818 r. miała jeszcze drugie seminarium, w Kielcach. Stan ten trwał do 1848 r. kiedy to rządca obydwóch częśsi diecezji, biskup pomocniczy Ludwik Lętowski, zrezygnował z zajmowanego stanowiska i odtąd część „,polska" i część , austriacka” otrzymały niezależnych ordynariuszów. Por. B. Kumor, Ustrój i organizacja Kościola polskiego w okresie niewoli narodowej (1792-1918). Kraków 1980, s. 210.

$7 \mathrm{~Np}$. w roku akademickim $1836 / 1836$ na Wydziale Teologicznym studiowalo tylko siedmiu studentów, z tego na pierwszym roku trzech, a na trzecim roku czterech słuchaczy. Wyjątkowy okazał się rok naslępny, gdyż na ten wydział zapisał się tylko jeden student, który w dodatku został skreślony. Rektor Lańcucki tłumaczy ten stan tym, że Statut Uniwersytecki dopuszczał do słuchania nauk publicznych na Wydziale Teologicznym tylko tych studentów, klórzy ukończyli gimnazjum oraz po wysłuchaniu pewnych wykładów na Wydziale Filozoficznym. Jednak drugą okoliczność podaje mało praklyczny sposób prowadzenia wykładów. AUJ SI 129. 
Po reorganizacji Wydziału Teologicznego w 1815/1816 zaczęli się zgłaszać słuchacze. Uniwersytet jednakże stawiał przed kandydatami duże wymagania. Każdy student, zgłaszający się na Wydział Teologiczny, prawa czy medycyny, powinien się wykazać uprzednio świadectwem ukończenia gimnazjum, uczęszczać przez dwa lata na wykłady z filozofii i dopiero po odebraniu zaświadczenia o zdaniu egzaminów mógł zgłosić się na odpowiedni wydzial ${ }^{8}$. Jeśli chodzi o teologię obowiązywal dodatkowy przepis, że student może się zapisać na wykłady najwyżej z 4 do 5 przedmiotów. Zalecano także wysłuchanie "Literatury Polskiej”". Statut z 1818 r. dla kandydatów zgłaszających się na studia wprowadzał jeszcze - oprócz świadectwa ukończenia gimnazjum - egzamin wstępny przed rektorem i profesorami gimnazjum lub przed dziekanem i profesorami wydziału filozoficznego. Studentów przybywających spoza Rzeczypospolitej Krakowskiej obowiązywało prawo przepisane dla ich własnych uniwersytetów ${ }^{10}$. Jako zwyczajny słuchacz student mógl się zapisać tylko na jeden wydział. Natomiast w zajęciach drugiego wydziału, np. prawa czy medycyny, mógł uczestniczyć - za zezwoleniem rektora czy dziekana - ale tylko jako wolny słuchacz ${ }^{11}$. Toteż obok zwyczajnych studentów byli także (choć w mniejszości) wolni słuchacze. Byli nimi albo teologowie uczęszczający zarazem na inne wydziały, albo studenci innych przedmiotów, zwłaszcza prawa, słuchający także teologii ${ }^{12}$. Warto podkreślić, że $w$ roku akademickim 1829/1830 widnieje w spisie studentów teologii Izraelita, który studiował język hebrajski.

Załączona (s. 162) tabela ilustruje różne aspekty życia studenckiego Wydziału Teologicznego UJ w Wolnym Mieście Krakowie. Musi nas uderzyć duża płynność frekwencji studentów w analizowanym okresie.

- Rektor UJ w piśmie do dziekana Wydzialu Teologicznego z 24 IV 1816 r. przypomniał uchwałe Rady Rektorskiej z 6 X 1815 r., że studentami zwyczajnymi wydziału mogą być tylko ci kandydaci, klórzy ,wykażą się świadectwem o odbytych studiach i zdanych egzaminach nauk: logiki, etyki, matematyki niższej, fizyki i historii naturalnej". AUJ WT I 15. Podobną uchwałe Rada Rektorska podjęła 25 VI 1819 r. AUJ SI 128. Por. także M. Patkaniowski, Dzieje Wydzialu Prawa Uniwersytefu Jagiellońskiego od reformy Kollataja do konica XIX wieku. Kraków 1964, s. 214.

${ }^{9}$ Rektor zgłosił to zalecenie dziekanowi Wydziału Teologicznego pismem z 2 XI 1816 r. AUJ WT I 4.

10 Pismo rektora do Wysokiej Rady Uniwersyteckiej z 14 XI 1818. AUJ S I 128.

"Student Wydziału Chirurgicznego, G. Pyziński, zwrócił się 21 X 1833 r. do Komisarza Rządowego J. Schindlera o pozwolenie uczęszczania na wykłady z teologii. Komisarz - powołując się na paragral 27 Statutu odpowiedział, że może być zwyczajnym studentem tylko na jednym wydziale, a na drugim tylko wolnym słuchaczem. Z takimi wypadkami spotykano się dosyć często. AUJ WT I 15.

$12 \mathrm{~W}$ roku $1830 / 1831$ na 8 słuchaczy było 4 księży, wśród nich ks. B. Baniakowski, który już studiował kilka lat, i ks. B. Maliński. AUJ D VII 26. 
Studenci Wydziału Teologicznego Uniwersytetu Jagiellońskiego wedlug ich pochodzenia społecznego i geograficznego

w latach $1815-1850$

\begin{tabular}{|c|c|c|c|c|c|c|c|c|c|c|c|c|c|c|c|c|c|}
\hline \multirow[t]{3}{*}{ Lp. } & \multirow[t]{3}{*}{ Lata } & \multicolumn{6}{|c|}{ Studenci } & \multicolumn{4}{|c|}{ Pochodzenle spoteczne } & \multicolumn{6}{|c|}{ Pochodzenie terytortalne } \\
\hline & & \multirow[b]{2}{*}{ 寻 } & \multirow[b]{2}{*}{ 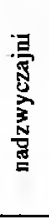 } & \multirow[b]{2}{*}{$\begin{array}{l}E \\
\frac{E}{0} \\
\vdots \\
0\end{array}$} & \multicolumn{3}{|c|}{ lata studión } & \multirow[b]{2}{*}{ 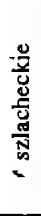 } & \multirow[b]{2}{*}{$\frac{\frac{.0}{2}}{\frac{m}{0}}$} & \multirow[b]{2}{*}{ 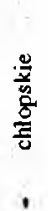 } & \multirow[b]{2}{*}{ 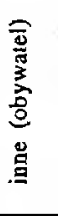 } & \multirow[b]{2}{*}{ 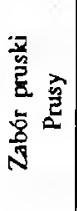 } & \multirow[b]{2}{*}{$\begin{array}{l}0 \\
\frac{3}{3} \\
\frac{3}{0} \\
\frac{3}{0} \\
0\end{array}$} & \multirow[b]{2}{*}{ 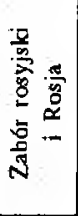 } & \multirow[b]{2}{*}{ 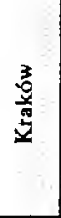 } & \multirow[b]{2}{*}{ 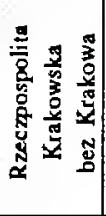 } & \multirow[b]{2}{*}{ 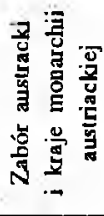 } \\
\hline & & & & & 1 & II & III & & & & & & & & & & \\
\hline 1. & $1815 / 16$ & 17 & - & 17 & 17 & - & - & 5 & 3 & 8 & 1 & 1 & 3 & - & - & - & 13 \\
\hline 2. & $18: 6 / 17$ & 10 & 1 & 11 & 4 & 7 & - & 3 & 4 & 3 & 1 & 1 & 3 & - & 1 & - & 6 \\
\hline 3. & $1817 / 18$ & 5 & 1 & 6 & 4 & 2 & - & 2 & 3 & - & 1 & - & 3 & - & 1 & - & 2 \\
\hline 4. & $1818 / 19$ & 9 & 3 & 12 & 10 & 1 & 1 & 2 & B & - & 2 & - & 4 & - & 3 & 2 & 3 \\
\hline 5 & $1819 / 20$ & 8 & 4 & 12 & 10 & 1 & 1 & - & 6 & 2 & 4 & 2 & 4 & - & 1 & 1 & 4 \\
\hline 6. & $1820 / 21$ & - & - & 23 & 21 & 2 & - & 1 & 7 & 5 & 10 & 4 & 6 & - & - & $i$ & 12 \\
\hline 7. & $1821 / 22$ & 21 & 6 & 27 & 22 & 5 & - & 4 & 17 & 5 & 1 & 3 & 5 & - & 1 & 1 & 17 \\
\hline a & $1822 / 23$ & 23 & 1 & 24 & 16 & 8 & - & 4 & 10 & 6 & 1 & 2 & 10 & - & 1 & 1 & 10 \\
\hline 9. & $1823 / 24$ & 18 & 4 & 22 & 15 & 5 & 2 & 3 & 14 & 5 & - & 2 & 6 & - & 3 & 1 & 10 \\
\hline 10. & $1824 / 25$ & 17 & - & 17 & 11 & 5 & 2 & 4 & 7 & 2 & 4 & 3 & 8 & 1 & 1 & - & 5 \\
\hline 11. & $1825 / 26$ & 18 & - & 18 & 13 & 5 & - & 1 & 10 & 3 & 4 & 3 & 2 & - & 2 & 1 & 10 \\
\hline 12. & $1826 / 27$ & - & - & 23 & 15 & 8 & - & 1 & 19 & 2 & 1 & 3 & 4 & - & 2 & 1 & 13 \\
\hline 13. & $1827 / 28$ & - & - & 30 & 24 & 6 & - & 5 & 11 & 2 & 11 & 4 & 5 & - & $4^{\prime}$ & 3 & 14 \\
\hline 14. & $1828 / 29$ & - & - & 21 & 10 & 11 & - & 2 & 6 & 3 & 10 & 3 & 3 & - & 3 & 3 & 9 \\
\hline 15. & $1829 / 30$ & - & - & 25 & 15 & 8 & 2 & 2 & 16 & - & 7 & 6 & 5 & - & 4 & 2 & 7 \\
\hline 16. & $1830 / 31$ & - & - & 18 & 8 & 5 & 5 & 2 & 10 & 1 & 5 & 5 & 6 & - & 4 & - & 3 \\
\hline 17. & $1831 / 32$ & 9 & 2 & 11 & 3 & 5 & 3 & - & 7 & 2 & 2 & 1 & 5 & - & 2 & - & 3 \\
\hline 18. & $1832 / 33$ & 12 & 2 & 14 & 8 & 4 & 2 & - & 9 & 2 & 3 & 1 & 1 & - & 4 & - & 8 \\
\hline 19. & $1833 / 34$ & 8 & - & 8 & 8 & - & - & - & 3 & - & 5 & - & - & - & 4 & 1 & 3 \\
\hline 20. & $1834 / 35$ & 7 & - & 7 & 2 & 4 & 1 & - & 3 & - & 4 & - & - & - & 3 & 1 & 3 \\
\hline 21. & $1835 / 36$ & 6 & - & 6 & 2 & - & 4 & - & - & - & 6 & 1 & - & - & 1 & - & 4 \\
\hline 22. & $1836 / 37$ & 1 & - & 1 & 1 & - & - & - & - & - & 1 & - & - & - & - & - & 1 \\
\hline 23. & $1837 / 38$ & 6 & 1 & 7 & 7 & - & - & - & - & 2 & 5 & - & - & - & - & 4 & 3 \\
\hline 24. & $1838 / 39$ & 9 & - & $\mathrm{g}$ & 2 & 7 & - & - & - & 1 & 8 & - & - & - & 3 & 3 & 3 \\
\hline 25. & $1839 / 40$ & 8 & 2 & 10 & - & 4 & 6 & - & - & - & 10 & 2 & 1 & 1 & 2 & - & 6 \\
\hline 26 & $1840 / 41$ & 5 & 3 & 8 & 6 & - & 2 & - & - & - & 8 & - & - & - & 4 & 2 & 2 \\
\hline 27 & $1841 / 42$ & 10 & 1 & 11 & 7 & 4 & - & - & 3 & 3 & 5 & - & 1 & J & 3 & 4 & 2 \\
\hline 28 & $1842 / 43$ & 11 & - & 11 & 2 & 4 & 5 & - & 2 & 2 & 7 & - & 2 & - & 1 & 3 & 5 \\
\hline 29 & $1843 / 44$ & 10 & 5 & 15 & 9 & 2 & 4 & 1 & 5 & 3 & 6 & 2 & 2 & - & 4 & 2 & 5 \\
\hline 30 & $1844 / 45$ & 9 & 7 & 16 & 5 & 5 & 6 & 1 & 4 & - & 9 & 2 & 3 & - & 5 & 2 & 3 \\
\hline 31 & $1845 / 46$ & 9 & 2 & 11 & 3 & 3 & 3 & $i$ & 3 & 1 & 6 & $i$ & 1 & - & 6 & - & 3 \\
\hline 32 & $1846 / 47$ & 5 & 1 & 6 & 3 & 2 & 1 & 1 & - & 1 & 4 & - & - & - & 4 & - & 2 \\
\hline 33 & $1847 / 48$ & 8 & - & 8 & 3 & 3 & 2 & - & - & - & 8 & - & - & - & 4 & - & 4 \\
\hline 34 & $1848 / 49$ & 10 & - & 10 & 4 & 2 & 4 & - & - & - & 10 & - & - & - & 1 & 1 & : \\
\hline 35 & $1849 / 50$ & 9 & - & 9 & 5 & . & - & - & 3 & 1 & 5 & - & - & - & 4 & - & 5 \\
\hline
\end{tabular}

- - brak danych źródlowych

- zjawisko nie wystepuje

Podstawa źródłowa: AUJ WT 116; WTI19; Katalogi studentów: dziekańskich I poszczególnych katedr. 
Wiadomo, że studenci stanowią element niezmiernie ruchliwy. Zmieniają uczelnie, przerywają studia itd. Toteż początkowy zapis studentów zawsze jest większy od stanu końcowego. Także na teologii znaczna część słuchaczy zwykle nie dotrwała do końca i liczba kończących rok była zawsze mniejsza od wpisu początkowego. Często ta różnica była bardzo duża ${ }^{13}$. Wpływały tu takie czynniki, jak: brak środków materialnych, niezdanie egzaminu, niedopelnienie formalności paszportowych itd. ${ }^{14}$

Jedną z najpoważniejszych przyczyn małej ilości studentów teologii jest brak na studiach uniwersyteckich studentów seminarium diecezjalnego oraz sposób traktowania przez władze seminaryjne tych studentów Wydziału Teologicznego. $\mathrm{Ci} \mathrm{z}$ absolwentów, którzy zgłaszali się do seminarium, celem otrzymania święceń kapłańskich, byli traktowani na równi z kandydatami zgłaszającymi się do seminarium po gimnazjum. Zgłaszających się absolwentów albo nie przyjmowano, albo odbytych przez nich studiów teologicznych nie honorowano i zobowiązywano ich do ponawiania studiów teologicznych od pierwszego roku ${ }^{15}$. Takie postępowanie Konstystorza Krakowskiego i władz seminarium wpływało ujemnie na nabór studentów na Wydział Teologiczny, gdyż ubożsi studenci udawali się wprost do seminarium i poprzestawali na naukach tam dawanych. Wedlug dziekana Wydziału Teologicznego, ks. Fl. Kudrewicza z 28 I 1818 r. słuchaczami nauk teologicznych na Akademii byli studenci

13 Wedhug pisma dziekana Wydziału Teologicznego ks. Fl. Kudrewicza z 28 I 1818 r. tylko 2 audytorów ukończyło „pełny kurs teologicznych nauk” w 1817/1818. AUJ S I 128. Dnia 26 VIII $1820 \mathrm{r}$. podał ks. Fl. Kudrewicz, że na 12 studentów w roku akademickim $1819 / 1820$ tylko 4 ukończyło studia. AUJ S I 422. W roku 1822/1823 spośród 24 studentów zdało egzamin 13, a tylko 1 ukończył studia. AUJ S 1 128. Podobnie ze sprawozdania ks. T. Teligi, dziekana tegoż wydziału, z 4 X 1842 r. wynika, że na 10 studentów zwyczajnych, trzech opuściło wydzial w ciągu roku; $W$ roku akademickim 1845/1846 z 10 studentów przy końcu roku zostało tylko 6 , a w roku $1848 / 1849$ na 20 studentów tylko połowa utrzymała się na wydziale do końca roku. AUJ S I 129.

14 Źródła często notują, że student został wykreślony „gdyż nie miał pozwolenia od swego rządu" - 1833/1834 AUJ SI 128, lub w 1836 wykreślony „z polecenia Komisarza Rzadowego". AUJ ST 129.

15 Dziekan Wydziału Teologicznego, ks. Kudrewicz, w piśmie do rektora UJ z 28 I 1818 r., wykazując tylko 6 studentów w roku akademickim 1817/1818, tłumaczy niską frekwencję na wydziale polityką władz seminaryjnych. Audytorzy uniwersytetu, po ukończeniu nauk teologicznych, którzy „udali się do Seminarium Krakowskiego jedynie dla nauczenia sie obrzędów i rubryk, albo nie byli przyjmowani, albo, gdy zostali przyjęci, byli uważani jako teologowie pierwszoletni z obowiązkiem słuchania na nowo calego kursu teologii seminaryjskiej..., którym odmówiono przyjęcia, udali się do innych diecezji: kieleckiej, gnieźnieńskiej, poznańskiej, gdzje odebrawszy natychmiast święcenia kaplańskie, są już ozdobą kleru przez spełnianie obowiązków parafialnych, lub też (przez) nauczanie po seminariach kleru sposobiącego się do stanu duchownego. Klórzy w tutejszym seminarium zostali, z tych żaden dotychczas święceń kapłańskich nie otrzymał". AUJ SI 128. 
innych wydziałów, $\mathrm{z}$ uwagi na zainteresowania lub powiązania $\mathrm{z}$ innymi naukami, lub studenci świeccy, którzy przybyli z innych diecezji, bowiem duchowni z diecezji krakowskiej, mimo chęci pogłębienia swoich studiów rezygnowali $z$ obawy narażenia się Konsystorzowi Krakowskiemu ${ }^{16}$. Sprawa ta przewijała się przez cały analizowany okres ${ }^{17}$.

$\mathrm{Na}$ stan studentów na Wydziale Teologicznym wpływały w bardzo dużym stopniu stosunki polityczne. Okres dziesięciolecia 1830-1840 charakteryzuje się wprost katastrofalnym spadkiem liczby studentów Wydziału Teologicznego, a nawet ich kompletnym brakiem w roku akademickim 1836/1837. Najprzód jest - to okres powstania listopadowego, a następnie, w jego wyniku, mieszanie się ,Dworów Opiekuńczych" w sprawy Uniwersytetu. I tak na rok akademicki 1832/1833 zgłosiło się na wykłady Pisma św. do profesora ks. Jana Schindlera ośmiu słuchaczy, z których w ciągu roku aż pięciu przestało uczęszczać na zajęcia ${ }^{18}$. $\mathrm{Na}$ rok akademicki 1835/1836 zapisało się tylko sześciu studentów (trzech na rok pierwszy i trzech na rok trzeci) ${ }^{19}$. Glównie $\mathrm{z}$ powodu interwencji rezydentów państw zaborczych na rok 1836/1837 zapisał się tylko jeden student, ks. Antoni Jałoszyński, lat 34, pełniący obowiązki wikarego przy kościele Św. Floriana. Ostatecznie jednak, jako poddany cesarstwa austriackiego, został skreślony $\mathrm{z}$ listy studentów, gdyż nie posiadał „wyoyczeźnienia" Rządu Cesarsko-Austriackiego, i pod koniec roku akademickiego Wydział Teologiczny był bez słuchaczy ${ }^{20}$. $\mathrm{Z}$ tego powodu zawieszone zostały zupełnie wykłady na Wydziale. W następnym roku widniało już na Wydziale siedmiu słuchaczy, wśród których był ks. Kazimierz Żurkowski. Pewne uzupełnienie stanowili studenci $\mathrm{z}$ innych wydziałów (głównie $\mathrm{z}$ prawa i medycyny), zapisujący się na wykłady $z$ teologii. W ciągu roku zapisał się jeszcze ks. Mikołaj Dębrowicz jako wolny słuchacz ${ }^{21}$. W ten sposób niebezpieczeństwo braku studentów zostało zażegnane.

Inną, również ważną przyczyną małej liczby studentów w uczelni krakowskiej był bezwzględny zakaz studiowania w Krakowie, wydany przez rządy zaborcze dla wszystkich poddanych nie mających na to osob-

${ }^{16} \mathrm{Ks}$. Fl. Kudrewicz wspomina, że ks. Michał Lechert, kanonik lateraneński, który przybył $\mathrm{z}$ innej diecezji, musiał zrezygnować ze studiów teologicznych na Akademii z powodu prześladowania przez Konstystorz Krakowski. AUJ SI 128.

17 Ten sam problem podnosił ks. Fl. Kudrewicz w piśmie z 26 VIII 1829 r. AUJ SI 422.

18 AUJ D VII 26.

19 Studentami pierwszego roku byli: Jan Orgler z Mysłowic lat 27, Jan Sałasz ze Skoczowa lat 22 i Leopold Szwiliński z Tarnowskich Gór lat 22; na trzeci rok zapisali się: Jan Droździewicz ze Skawiny, lat 23, Adam Fedorowicz z Chyliny, lat 22 i Mateusz Solarski z Krakowa, lat 27. Wszyscy kończyli gimnazjum w Krakowie. AUJ D VII 26.

${ }^{20}$ T. Glemma, Wydzial Teologiczny..., s. 139.

${ }^{21} \mathrm{~W}$ roku akademickim $1837 / 1838$ na 7 słuchaczy, 3 przybyło z filozolii, a 1 z medycyny. AUJ D VII 26. 
nego pozwolenia, którego w zasadzie nigdy nie udzielano ${ }^{22}$. W wyniku zaburzeń studenckich w 1820 r., wykrycia tajnej organizacji studenckiej oraz szeregu innych momentów politycznych w Wolnym Mieście Krakowie władze Królestwa Polskiego zakazaly w 1823 r. swoim obywatelom zapisywać się na Uniwersytet Jagielloński. Mimo usilnych zabiegów Senatu Rządzącego W. M. Krakowa, Wielki Książę Konstanty nie cofnął wydanego zakazu i młodzież z Królestwa musiala opuścić Kraków. Po powstaniu listopadowym ponowiono zakaz przyjmowania na Uniwersytet Jagielloński. Wladze austriackie wprawdzie nie odwołały młodzieży z Galicji, ale również zaczęły stosować politykę utrudniania młodzieży podejmowania studiów na Uniwersytecie Jagiellońskim ${ }^{23}$.

Szczególnie po powstaniu listopadowym tropiono na uniwersytecie uczestników powstania. Jeszcze w 1833 r. dziekan Wydziału Teologicznego otrzymał zakaz komunikowania profesorom i studentom obwieszczenia Senatu Rządzącego, aby „byli wojskowi polscy i osoby cywilne zagraniczne, które miały udział w Rewolucji Królestwa Polskiego w 1830/1831 ...opuściły tutejszy kraj" ${ }^{24}$. Dziekan Wydziału Teologicznego, ks. Leon Laurysiewicz, w sprawozdaniu z Wydziału z 27 IX 1841 r., podając tylko 10 studentów wyjaśnial małą ich liczbę tym, że wielu ubiegających się kandydatów, którzy nie złożyli potrzebnych zaświadczeń w roku $1839 / 1840$, zostało skreślonych ${ }^{25}$. Kontrola policyjny była bardzo ostra. Komisarz rządowy przesyłając dziekanowi Wydziału Teologicznego nie odebrane przez studentów ,imatrykuly” ostrzegal zapisujących się na uniwersytet, że ich nic ,przed Dyrekcją Policji za jakie bądź uchybienie zaslonić nie potrafi" ${ }^{26}$.

W następnym okresie 1839-1847 liczba słuchaczy była nadal jeszcze mala, ale $\mathrm{w}$ porównaniu $\mathrm{z}$ okresem poprzednim stan nieco się polepszyl. $\mathrm{Z}$ uznaniem należy podkreślić, że duży odsetek studentów teologii w niektórych latach stanowili księża i klerycy seminarium diecezjalnego oraz zakonnicy. W roku akademickim 1819/1820 studiowało na Uniwersytecie 8 kleryków, a roku następnym było ich już 14 . Księża stanowili mniejszy odsetek, ale też prawie co roku widnieją w spisie studentów. W roku 1839/1831 studiowało 5 księży. Wśród 10 studentów zapisanych w roku 1839/1840 było 3 księży wikarych: Makary Baniakowski (Św. Anna), Adam Fedorowicz

22 Kurator Generalny Instytutów Naukowych M. M. Krakowa przypomniał władzom unjwersytetu, że kandydaci na studia przybywający spoza granic Rzeczypospolitej Krakowskiej winni przedlożyć przy wpisie paszporly wraz z pozwoleniem na studia od rządu swego kraju. AUJ rkp. SI 305.

${ }^{23}$ Por. M. Kulczykowski, dz. cyt., s. 34.

24 T. Glemma, Wydzial Teologiczny..., s. 140.

25 AUJ SI 129.

26 AUJ D VII 26. 
i Leopold Szwiliński (Św. Mikołaj). Ten ostani przerwal swe studia w ciągu roku. Zwiększoną frekwencję studentów można uzasadnić uczęszczaniem w tych latach na studia kaplanów zakonnych: augustianów, dominikanów, paulinów. Niespokojne czasy sprawiły, że w następnych latach znów spada liczba studentów do sześciu w roku 1846/1847, i to samych księży.

\section{POCHODZENIE SPOLECZNE STUDENTÓW WYDZIAŁU TEOLOGICZNEGO}

Ważnym zagadnieniem jest pochodzenie społeczne studentów. Dla celów klasyfikacyjnych wyróżniono podział na cztery grupy społeczne: szlachta, mieszczanie, chłopi i inni. Do tej ostatniej grupy zaliczono tych, których rodzice tytułowali się obywatelami. Jeśli na początku analizowanego okresu studenci pochodzenia szlacheckiego stanowili znaczny odsetek, to po roku 1830 ustaje zupelnie naplyw kandydatów na teologię spośród szlachty. To zjawisko należy tłumaczyć wypadkami związanymi z powstaniem listopadowym i znacznym zaangażowaniem się młodzieży szlacheckiej w powstanie. Dopiero pod koniec istnienia Rzeczypospolitej Krakowskiej znowu pojawiają się studenci teologii zaliczani do tej grupy społecznej. Należy także wziąć pod uwagę, że studia teologiczne w tym okresie już nie dawały promocji ani pod względem społecznym, ani tym bardziej pod względem materialnym ${ }^{27}$.

Mimo przysłowiowej „nędzy galicyjskiej” i zniesienia pańszczyzny w zaborze austriackim dopiero po tzw. rabacji w 1846 r., studenci pochodzenia chłopskiego stanowili nieco wyższy procent od poprzedniej grupy. Jednakże przez cały analizowany okres dominowali na studiach teologicznych synowie rodzin mieszczańskich i małomiasteczkowych (obywateli). To zjawisko należy łączyć $\mathrm{z}$ większymi możliwościami finansowymi tych rodzin przy wysyłaniu synów do szkół średnich i na studia wyższe.

W ogóle opłaty za studia odgrywały ważną rolę w budżecie studentów teologii. Gdy w 1818 r. ks. T. Mazurkiewicz, dziekan Wydziału Teologicznego ogłosił studentom zarządzenie rektora o ustaleniu wysokości taksy egzaminacyjnej na $50 \mathrm{zlp.,} \mathrm{wszyscy} \mathrm{studenci} \mathrm{oświadczyli,} \mathrm{że} \mathrm{nie} \mathrm{będą} \mathrm{mogli}$ jej uiścić, gdyż utrzymują się $z$ kondycji ${ }^{28}$. Dużą pomocą dla studentów były stypendia zwane ,,borkarzami”" 29.

${ }^{27}$ Ks. B. Kumor zwraca uwage na niskie uposażenie kleru w diecezji tarnowskiej w XIX wieku. Por. Diecezja Tarnowska. Dzieje ustroju i organizacji 1786-1985. Kraków 1985 , s. 484.

28 AUJ D VII 26.

${ }^{29} \mathrm{Na}$ posiedzeniu Rady Wydziału Teologicznego w dniu 7 VII 1825 r. wytypowano aż dwunastu studentów, którzy wykazali pilność w studiach, celem przyznania im stypendium, 


\section{POCHODZENIE GEOGRAFICZNE STUDENTÓW WYDZIALU TEOLOGICZNEGO}

Bardzo różnorodne jest również pochodzenie geograficzne studentów Wydziału Teologicznego. Do wyjątków należą studenci z zaboru rosyjskiego, z Litwy. Natomiast do 1831 r. prawie corocznie naplywało po kilku studentów z zaboru pruskiego, głównie ze Śląska, oraz z Królestwa Polskiego. Przez kilka następnych lat po powstaniu listopadowym $z$ obu tych regionów geograficznych nie było żadnego studenta. Pojawiają się dopiero pod koniec badanego okresu. Zatem przez cały analizowany okres głównym regionem, z którego napływali studenci teologii, była Rzeczypospolita Krakowska wraz z Krakowem oraz zabór austriacki, glównie z terenów Pogórza Karpackiego ${ }^{30}$.

\section{DYSCYPLINA STUDIÓW}

Sytuacja polityczna, jaka zapanowała w początkach powstania Wolnego Miasta Krakowa pozwalala młodzieży akademickiej na dużą swobodę postępowania. Artykuł XV Traktatu Wiedeńskiego z maja $1815 \mathrm{r}$. zapewnial mlodzieży dawnych prowincji polskich, graniczących z Rzeczypospolitą Krakowską swobodny dostęp na Uniwersytet Jagielloński. Jednakże w miare jak „,Trzy Dwory Protekcyjne” zaostrzały przepisy administracyjne dla Uniwersytetu, wzrastały także wymogi dyscyplinarne samych studiów. Po wydarzeniach $\mathrm{z}$ lipca $1820 \mathrm{r}$., związanych $\mathrm{z}$ aresztowaniem trzech studentów i manifestacją młodzieży, zakazano młodzieży z Królestwa Polskiego dostępu na studia w Krakowie i wprowadzono paszporty z pozwoleniem od Władz Rządowych danego kraju ${ }^{31}$. Zaostrzono także

tzw. „borkany”. W następnym roku na podobnym posiedzeniu 26 maja przyznano stypendia pięciu studentom. AUJ WT I 3.

30 Por. Tabl. nr 1.

31 W latach 1838-1849 żódła notują szereg przypadków skreślenia z listy studenckiej rocznje nawet po kilku studentów z powodu braku pozwolenia właściwego rządu na uczęszczanie lub paszportu emigracyjnego. AUJ SI 425; Np. w 1849 r. oprócz 10 studentów zwyczajnych było zapisanych jeszcze innych 10, w tym 3 dominikanów i 1 kapelan wojsk cesarskich, ale w ciągu roku akademickiego zostali "wyskrybowani" z braku właściwych allegeatów. AUJ SI 434. Warto tu wspomnieć, że mimo tak ostrych sankcji Wydział Teologiczny starał się być tolerancyjny dla studentów spoza Rzeczypospolitej Krakowskiej. W źródlach w roku akademickim 1840/1841 jest notatka o studencie A. Kwiatkowskim: „Uczeń ten pierwszoleıni na Wydział Teologiczny nie został przyjęty dla braku pozwolenia od właściwego urzędu, jednakowoż jako dobrze aplikujący się był tolerowany". AUJ SI 434. 
dyscyplinę na samej uczelni zarówno w stosunku do studentów ${ }^{32}$, jak i profesorów ${ }^{33}$. Dla łatwiejszej kontroli zachowania się studentów Senat Rządzący Wolnego Miasta Krakowa, na wiosek Kuratora Instytutów Naukowych, przepisał - zarówno dla uczniów liceum, jak i dla studentów Uniwersytetu - obowiązek noszenia mundurów, co zostało wprowadzone $\mathrm{z}$ początkiem roku akademickiego $1826 / 1827^{34}$. W następnych latach często przypominano dziekanom o obowiązku noszenia mundurów przez studentów. Początkowo Kurator Instytutów Naukowych zwolnil od tego obowiązku osoby duchowne, ale w roku akademickim 1829/1830 na nowo wprowadzono dla stanu duchownego strój duchowny lub zakonny, a dla świeckich fraki granatowe lub ciemno-szaraczkowe surduty ${ }^{35}$. Statut $\mathrm{Ku}-$ ratorski z $1826 \mathrm{r}$. zaostrzał także dyscyplinę obecności na wykładach. Studentowi za opuszczenie $w$ ciągu miesiąca 3 wykładów bez należytego usprawiedliwienia, grozilo skreślenie $z$ listy studentów ${ }^{36}$. Podobne wymogi stawial Statut z 1831 r. ${ }^{37}$ Podczas powstania listopadowego zaostrzono

32 Pismem z 24 X 1820 r. rektor UJ zawiadomil dziekana Wydziału Teologicznego o konieczności ponownego zgłoszenia się studentów do kancelarii do dnia 4 listopada, celem otrzymania zaświadczenia, że jest studentem. To zaświadczenie może student otrzymać po polwierdzeniu przez 2 profesorów, że zapisał się na ich wykłady. Na zapis po 4 listopada może dać zgodę tylko dziekan. AUJ WT I 21.

${ }^{33}$ Innym pismem z 2 listopada 1820 r. rektor zawiadomił dziekana Wydziału Teologicznego, że według paragrafu 62 Urządzen Wewnętrznych każdy dzjekan ma najbliższy dozór nad studentami swego wydziału $\mathrm{i}$ jest obowiązany zasięgać wiadomości o sprawowaniu się swych podopiecznych tak na samej uczelni, jak i poza nią. AUJ WT I 21. Dnia 8 XI $1824 \mathrm{r}$. rektor wezwał dziekanów wszystkich 5 wydziałów do odebrania od profesorów katalogów studentów. Dziekan Wydziału Teologicznego przekazał profesorom postanowienie Rady Rektorskiej, aby katalogi były od czasu do czasu sprawdzane na wykładach. Także na wykładach powinno się odczytywać przepisy karne. Nie wolno także pozwalać na uczestniczenie w wykładach wolnym słuchaczom, jeśli nie mają pozwolenia od reklora. AUJ WT I 15. Rada Rektorska przypomniała 17 XI 1826 r. dziekanom o obowiązku dozoru nad profesorami i studentami swego wydziału. Komisarz Rządowy zażądał 7 lipca 1836 r. od dziekana Wydziału Teologicznego nadesłania zaraz po zakończeniu egzaminów publicznych do kancelarii uniwersytetu raportu o postępie w studiach i obyczajach studentów. Podobne żąanie wystosował w następnym roku. AUJ WT I 15.

34 AUJ SI 136. Zwolnienie $\mathrm{z}$ noszenia munduru zależało od Kuratora Instytutów Naukowych. Dzięki wstawiennictwu rektora takowe otrzymał student J. Gudrajczyk, gdyż miał tylko 5 miesięcy do zakończenia studiów uniwersyteckich, po których postanowił wstąpić do seminarium i potrzebował pieniędzy na opłatę studiów. AUJ WT I 21.

${ }^{35} \mathrm{~Np} .3$ XI 1828, 18 X 1830, WT I 21.

${ }^{36}$ Rektor 15 XI 1827 r. odwoływal się do swej odezwy nr 738 z 17 XI 1826 r. AUJ WT 115.

37 Rektor w liście z 5 III 1831 r. przypomniał dzjekanowi Wydziału Teologicznego uchwałe Wielkiej Rady Uniwersyleckiej, zobowiązującej dziekana do czuwania, aby studenci „z miejsca oddali się pilnie i regularnie nauce... pod rygorem ich wykreślenia, gdyby nie uczęszczali na lekcje". AUJ WT I 15. 
obowiązek uczestniczenia w wykładach, a nawet samo chodzenie po mieście ${ }^{38}$. Ten kurs ustawicznego nadzoru nadal obowiązywał nawet już po ustaniu działań powstańczych. Dnia 14 XII 1833 r. Senat Rządzący podjął uchwałę, że uczeń wpisany do albumu studenckiego był zobowiązany do zlożenia rektorowi zobowiązania świadczenia posłuszeństwa zwierzchności Uniwersytetu ${ }^{39}$. W oparciu o tę nową ustawę porządkową Komisarz Rządowy przy Instytutach Naukowych w piśmie z 24 VII 1834 r. domagal się od dziekana Wydziału Teologicznego, „by profesorowie uzgadniali między sobą ocenę obyczajności studentów" 40. W dwa lata później, 5 XI 1836 r., Senat Rządzący podjął uchwałę, że o obyczajności ,intra muros" Uniwersytetu orzekają profesorowie, natomiast „extra muros" polecono policji czuwać nad młodzieżą i donosić do władz edukacyjnych ${ }^{41}$. Późniejsze modyfikacje do Statutu Uniwersyteckiego z 1833 r. obejmowały formularze, w których student był obowiązany podać szczegółowo swoje personalia - „pod osobistą ...zwierzchników odpowiedzialnością" - łącznie z takimi danymi jak: paszport czy pozwolenie wlaściwej władzy rządowej, środki utrzymania, miejsce zamieszkania, dokonane opłaty uniwersyteckie itd. Katalog studencki z tymi danym personalnymi byl obowiązany dziekan wydziału w jednym egzemplarzu przekazać rektorowi, a drugi egzemplarz, pozostający w aktach dziekańskich, przesłać do kontroli Komisarzowi Rządowemu ${ }^{42}$.

Wypada jednakże wspomnieć, że podjęto także kroki, by zwiększyć napływ kandydatów na studia teologiczne. Stosownie do $X$ artykułu Urządzenia Wewnętrznego Senatu z 1833 r., wydanego przez Komisję Reorganizacyjną, Senat Rządzący podjął uchwakę, ze począwszy od 31 X 1836 r. nie będzie mógl być mianowany na beneficja Kollacji Rządowej żaden kandydat, który nie ukończyl pelnego kursu teologii na Uniwersytecie Krakowskim lub w którymś $z$ uniwersytetów z Trzech Państw

38 Rektor w piśmie z 29 XI do dziekana Wydziału Teologicznego polecił upomnieć studentów, ,aby żaden $\mathrm{z}$ nich tego dnia nie wyszedł z domu w jakimkolwiek zamiarze pod karą wykluczenia z Instytutów Naukowych, a nawet kryminalną". Pismo rektora do dziekana Wydziału Teologicznego z 26 I 1831 r. zalecało studentom uczestniczenie w wykładach i przestrzeganie przepisów karności „pod karą natychmiastowego usunięcia z Uniwersytetu”. Podobny wymóg stawiał rektor $w$ piśmie z 30 I 1832 r. AUJ WT I 21.

${ }^{30}$ Ta ustawa porządkowa zabraniała studentom: a. gry w pieniądze i fanty, b. schadzek, c. zakładania towarzystw pod jakimkolwiek imieniem. Za nieprzesirzeganie dyscypliny groziły im kary: a. napomnienia ze strony profesora. b. napomnienie dziekana, c. napomnienie Rady Wydzialu, d. wydalenie z Uniwersytetu (ciche lub za większe przestępstwa - jawne). AUJ WT I 21.

to AUJ WT I 21.

${ }^{41}$ Komisarz Rządowy przekazał 16 XI 1836 r. dziekanowi Wydziału Teologicznego to zarządzenie Senatu Rządzącego z 5 XI tegoż roku. AUJ WT I 21.

42 AUJ WT I 15. 
Opiekuńczych. O tej uchwale powiadomiono władzę diecezjalną ${ }^{43}$. Wprawdzie źródła archiwalne zawierają wzmianki o jakichś napisach w salach wykladowych nie licujących $\mathrm{z}$ powagą miejsca, a mających charakter patriotyczny, na ogół jednak sprawozdania profesorów Wydziału Teologicznego dają bardzo pozytywne opinie o swoich słuchaczach ${ }^{44}$.

43 AUJ SI 310.

44 Np. sprawozdanie dziekanów Wydziału Teologicznego dla rektora ks. M. Jankowskiego z 30 IV 1827 czy ks. T. Teligi z lat 1843-1845. AUJ SI 128; SI 129; WT I 6. 